\title{
Investigation of Mathematical Modeling Processes of Middle School Students in Model-Eliciting Activities (MEAs): A STEM Approach
}

\author{
Şule Deniz \\ Department of Mathematics and Science Education, Mersin University, Mersin, Turkey \\ ORCID: 0000-0002-3119-7403
}

Gamze Kurt

Department of Mathematics and Science Education, Mersin University, Mersin, Turkey ORCID: 0000-0002-3119-7403

\begin{tabular}{|c|c|}
\hline Article history & $d$ \\
\hline $\begin{array}{l}\text { Received: } \\
25.03 .2021\end{array}$ & $\begin{array}{l}\text { difficulties encountered in model-eliciting activities (MEAs) of 8th- } \\
\text { grade students in a STEM education setting. This qualitative research is }\end{array}$ \\
\hline $\begin{array}{l}\text { Received in revised form: } \\
11.05 .2021\end{array}$ & $\begin{array}{l}\text { a case study conducted at a public school located in the central districts } \\
\text { of a large province in the Mediterranean Region. The participants of the } \\
\text { study are groups of 8th-grade middle school students in a classroom (five }\end{array}$ \\
\hline $\begin{array}{l}\text { Accepted: } \\
02.06 .2021\end{array}$ & $\begin{array}{l}\text { groups of students), which were selected with the purposeful sampling } \\
\text { method in the 2019-2020 academic year. The student groups were }\end{array}$ \\
\hline Key v & applied an MEA according to a certain plan, and the students' model- \\
\hline $\begin{array}{l}\text { Mathematical modeling, } \\
\text { Model eliciting activities, } \\
\text { Mathematical modeling } \\
\text { processes, STEM education, } \\
\text { middle school students }\end{array}$ & $\begin{array}{l}\text { eliciting processes were recorded. Then, the participants modeling } \\
\text { activity process and the cognitive activities they put forward through } \\
\text { documents and interviews were examined by considering the stages in a } \\
\text { mathematical modeling process. For this purpose, each group's modeling } \\
\text { process was analyzed qualitatively using the modeling cycle of Blum and } \\
\text { Borromeo Ferri (2009). The results of the study revealed that these 8th- } \\
\text { grade students faced some difficulties in the process of modeling. These } \\
\text { difficulties were identified in } 7 \text { categories: understanding the problem, } \\
\text { establishing a model, using mathematics, and explaining the results, - } \\
\text { which are the four stages of the modeling process- working within a } \\
\text { group, verifying the created model, and time management. }\end{array}$ \\
\hline
\end{tabular}

\section{Introduction}

Today, individuals with mathematical thinking, problem-solving, and mathematical modeling skills are needed in many fields, and it is not enough to memorize only mathematical operation processes and apply this method to similar problem situations (Lesh \& Zawojewsky, 2007). In order to prepare students for their future beyond school, it is necessary to ensure that they encounter and have experience in complex problem situations that enable them to develop their mathematical thinking and understanding of new concepts. At this point, the mathematical model and modeling approach are effective in solving complex problems that represent reallife situations in which students actively participate (Sriraman \& Lesh, 2006). Although many of the questions in exams such as TIMMS and PISA do not fully match the questions in mathematical modeling activities, it is stated that they are related to the steps of the mathematical modeling process, and as the difficulty level of the questions increases, the rate of including the steps of the mathematical modeling process increases (Turner, 2007). 
Mathematical modeling provides students with a mathematical understanding and activities that highlight mathematical concepts (Doğan, Gürbüz, Çavuş Erdem \& Şahin, 2019b; Kertil \& Gürel, 2016; Sriraman \& Lesh, 2006). It is important for middle school students to face reallife problems during the model-eliciting activity (MEA) process, as it is a study that makes them think about how prepared they are to solve real-world problems that they will face in their future professions or as individuals, both inside and outside of school and university (Lesh \& Zawojewsky, 2007; Stansell, Tyler-Wood \& Austin, 2016). In addition, it is thought that this study will make important contributions to teachers in determining what kind of role they should have in eliminating the difficulties in the process and the quality, content, and instruction of the activity to be implemented.

Considering these needs, it is clear that mathematical modeling is important in school mathematics. Therefore, it is necessary to improve students' modeling skills using mathematical modeling approaches during mathematics instruction. For this reason, in this study, we aimed to determine how much middle school students could use mathematics to understand and interpret real-life situations using MEAs, examine the modeling processes, identify the difficulties they encountered in this process, and understand their current situation. In addition, revealing the reasons for the difficulties faced by the students in the MEA process and developing solutions to eliminate these difficulties are among the aims of the study.

One of the effective ways to integrate mathematical modeling is to use the STEM approach. The fundamentals of doing mathematics are mainly based on how teaching mathematics is intertwined with real life. An instruction of mathematics disconnected from life demotivates students and prevents them from succeeding in mathematics. For this reason, prejudice and fear are developed against mathematics, and it causes mathematics to be considered difficult (Umay, 1996). The student-centered mathematics education approach that allows students to express themselves comfortably and includes everyday life problems is a prerequisite for successful mathematics education (Umay, 1996).

The STEM (namely the abbreviation made up of the initials of the words viz. Science, Technology, Engineering, and Mathematics) education approach, which emphasizes the relations of mathematics with other lessons and daily life problems and aims to raise interest in technology and engineering by teaching students the application areas of mathematics, can be a promising approach for effective mathematics teaching. The STEM education approach has soon become widespread worldwide, especially in developed countries where important studies have been conducted on this education approach (the Observatory on Borderless Higher Education [OBHE] Report, 2013). The Ministry of National Education in Turkey has not been indifferent to the STEM education approach and has published a report explaining the general situation (Ministry of National Education [MoNE], 2016). However, schools' educational practices and teaching methods are insufficient to raise individuals as required by the $21 \mathrm{st}-$ century society (Bulgar, 2008). In this respect, there is a need for STEM education, which is an approach that can provide 21st-century skills such as problem-solving, creativity, analytical and critical thinking, collaboration, and communication (Şahin, Ayar, \& Adigüzel, 2014).

STEM education is widely considered as an integrated education approach (Bryan, Moore, Johnson, \& Roehring, 2015). According to this understanding, it is based on the application of appropriate technologies by integrating teaching and learning processes in mathematics and science with engineering practices (Bryan et al., 2015).

One of the main aims of the middle school mathematics program is to raise individuals who 
can understand mathematical concepts and use them in their daily lives (MoNE, 2018). In the program, emphasis is placed on associating with everyday life many learning objectives targeted at almost every grade level. It is stated that knowledge and skills can be acquired through STEM activities created by combining multiple STEM fields (Çorlu, Capraro, \& Capraro, 2014). Besides, it is possible to organize STEM education activities in-class or outof-class with some differences (Şahin, Ayar, \& Adıgüzel, 2014). Examples of STEM activities have been encountered for different courses; however, examples of activities that might be integrated into the school program, especially in mathematics lessons, have not been as common as in other areas. Mathematical concepts are also addressed in activities where science concepts are common, but they are often limited in promoting mathematical thinking processes. Therefore, this study is important because it shows an example of the instruction of the STEM approach providing a mathematical modeling environment.

This study aimed to examine the mathematical modeling processes of middle school 8th-grade students through MEAs and STEM applications and determine the difficulties they might encounter. For this purpose, answers to the following research questions are sought:

(1) How does the mathematical modelling process of middle school $8^{\text {th }}$ grade students occur during MEAs in STEM education?

(2) What difficulties might middle school 8th-grade students encounter in the mathematical modeling process during MEAs in STEM education?

\section{Mathematical Model and Mathematical Modeling}

Mathematical models are conceptual tools needed to interpret individuals' problems mathematically (Kertil, 2008). Mathematical models can sometimes be shown with pictures, diagrams, symbolic shapes, tables, and words (English \& Mousoulides, 2011; Hestenes, 2010; Olkun \& Toluk Uçar, 2009). In general, modeling describes a process, while the model is the product that is revealed at the end of the process. According to Lesh and Doerr (2003), models are systems (formulas, drawings, graphs, shapes) in which conceptual structures are made sense, and conceptual relationships are defined. Mathematical model and modeling are explained as the ability to make complex mathematical systems meaningful using the language of mathematics (Lesh \& Doerr, 2003). Lesh and Doerr (2003), who are considered as two of the founders of the mathematical modeling approach, used the concept of model eliciting by combining the terms mathematical model and mathematical modeling.

\section{Mathematical Modeling (Model Eliciting) Process}

Approaches that define mathematical modeling differently and use it for different purposes have two main points that are regarded common: the first is that mathematical modeling consists of a process; the second is that some cognitive structures arise due to transitions between real life and mathematics. When studies conducted on the mathematical modeling process are examined, it is usually stated that the process involves a cyclic structure (Doerr, 1997; Borromeo Ferri, 2006; Hıdıroğlu, 2012; Lesh \& Doerr, 2003). Besides, it is seen that some studies explain the mathematical modeling process with steps (Lesh \& Doerr, 2003; Mason, 1988), while others describe it with figures (Berry \& Houston, 1995; Doerr, 1997; Lesh \& Doerr, 2003; Blum, 2011; H1dıroğlu, 2012). In this study, using the mathematical modeling cycle of Blum and Borromeo Ferri (2009) (see Figure 1), the mathematical modeling processes of two groups of four students, consisting of middle school 8th-grade students, were analyzed through an MEA, and the difficulties they encountered were tried to be determined. 
MEAs are defined as problem-solving activities where students can use mathematical modeling in complex real-life problems, create models, and explain, test and edit these models (Chan, 2008). They are mathematical modeling activities designed specifically to be used in teaching processes in line with mathematics teaching programs (Moore, Doerr, Glancy, \& Ntow, 2015; Chamberlin and Moon 2008).

In the relevant literature, it is stated that middle school students go through processes such as understanding, solving, testing, and revising the problem situation during the application of MEAs (Balakrishnan, Yen \& Goh, 2010; Lesh \& Harel, 2003). Thanks to the social interaction in the groups, they carried out these processes very successfully (Galbraith \& Stillman, 2006; Mousoulides, Pittalis, \& Christou, 2006). Especially since students work within a group, these activities offer many benefits such as criticizing each other, discussing and reaching the most relevant result (Zawojewski, Lesh, \& English, 2003), use of mathematical skills, use of mathematical language and tools, and understanding of the relation of mathematics with engineering and other disciplines. (Swan, Turner, Yoon, \& Muller, 2007) However, students also faced some difficulties in the whole process (Blum \& Leiß, 2007; Blum \& Borromeo Ferri, 2009; Eraslan \& Kant, 2015; Sol, Giménez \& Rosich, 2011 Greefrath, 2013).

\section{STEM Education Approach and Mathematics Education}

Mathematics is an important discipline with a direct or indirect relationship with many branches of science which are at the heart of scientific and technological developments (Eş, Özdemir \& Kaplan, 2019). Countries that want to produce technology and knowledge recognize the importance of education, especially in the fields of science and mathematics (Yamak, Bulut \& Dündar, 2014). In this regard, mathematical competencies open doors to a good future, so these competencies need to be provided and supported with opportunities to understand and learn mathematics in depth (National Council of Teachers of Mathematics [NCTM], 2000). It was stated that the middle school mathematics program, created as an integrated curriculum that guides the use of metacognitive skills, provides meaningful and permanent learning, is associated with solid and previous knowledge, and is integrated with other disciplines within the framework of values, skills, and competencies in daily life. (MoNE, 2018). STEM education should be prioratized in our country to improve students' scores in international exam such as PISA and TIMSS (MoNE, STEM Education Report, 2016).

Although many of the PISA questions do not fully match the questions in mathematical modeling activities, it is stated that they are related to the steps of the mathematical modeling process, and as the difficulty level of the questions increases, the rate of including the steps of the mathematical modeling process increases (Turner, 2007). Integrating mathematical concepts in daily life by creating associations among them enables students to learn effectively (Ben-Chaim, Fey, Fitzgerald, Benedetto \& Miller, 1997). Based on the fact that one of the determining elements of curriculum studies is state policies and these policies are not separate from economic realities (Kuenzi, 2008; Organization for Economic Cooperation and Development [OECD], 2010); it is stated that the STEM education approach, which includes daily life problems and emphasizes the importance of interdisciplinary learning, can bring a different perspective to mathematics education, and mathematical modeling can be used as a tool in the transition to STEM education (Doğan, Şahin, Çavuş Erdem \& Robust, 2019a; English, 2009; English \& Kirshner, 2015; Kertil \& Gürel, 2016). 


\section{Method}

\section{Research Design}

This study is a qualitative study in which the mathematical modeling/modeling processes of middle school 8th-grade students are determined with a STEM education approach using MEAs and the difficulties that arise in this process, and the reasons are explained. The aim of the study is the in-dept examination of students' modeling processes through multiple data sources (interviews, observations, worksheets, audio-visual materials, documents, and reports) to answer the research questions. For this reason, this study is a case study that is defined as the in-depth examination and analysis of a group or event in the most general sense (Patton, 2014; Yin, 2017). The case to be examined in our study is a class that is divided into groups of students determined to investigate the mathematical modeling processes, describe the difficulties that arise in the process, and describe how students work on MEAs. Case study is the integrated analysis of a case or more than one case within their own borders (Y1ldirım \& Şimşek, 2011) and investigation of the real life within the current context or environment (Creswell, 2018)

\section{Study Group}

The participants of the study are the students of an 8th-grade class in a public school where the researcher teaches. We employ some criteria to determine which class to choose using the purposeful sampling method. "In purposeful sampling, researchers purposefully select individuals and research locations to learn about the main phenomenon or to understand it" (Creswell, 2019, p.267). Besides, purposeful sampling is useful in discovering and explaining facts and events in many cases (Yıldırım \& Şimşek, 2011). This class was determined as the study group in the following way: A STEM activity was applied in this class the previous year, and the students learned the STEM approach. Besides, the researcher had been a mathematics teacher of this class for four years, and she had a good communication with students and knew about their characteristics. The students had less difficulty attending the school, and the class size was larger than that of the other four classes. Their parents volunteered to participate in the study process. The class consisted of 20 female students at a middle school in the city center. The students in the class were divided into five groups of 4 people based on their characteristics. Each group carried out the given activities and participated in the MEA process. Since the activities were carried out within the framework of a plan during the course hours, all students were included in the process. As long as the students in the class were not absent, they attended the MEAs, which were applied as planned every week. However, since it would be difficult to observe the whole class and ensure each group's continuation, the data collected from only two groups were analyzed.

Out of the five groups created, two were determined as focus groups by the criterion sampling method, which is one of the purposeful sampling strategies. In criterion sampling method, criterion or criteria can be determined by the researcher, or a list of criteria can be created (Yıldırım \& Şimşek, 2011). The criteria in deciding these two groups are the students' low absenteeism rates and their willingness to participate in the study process. They took a project assignment in the mathematics course, and the groups were heterogeneous in terms of success levels. Therefore, the only data analyzed in the study are the data obtained from the MEA process of these two groups. 


\section{Data Collection Tools}

Fundamental data collection tools in this study are one-to-one and group interviews (semi-structured), observations (field notes), audio-visual materials (video and audio recordings, photographs), and documents (MEA sheets, research logbooks, student reports, group evaluations, and presentation evaluation forms).

\section{Data Collection Process}

The data collection process consists of six course hours over five weeks and interviews (conducted outside the class hours). In this study, as a result of the relevant literature review, an interdisciplinary MEA named "Parking Lot Problem" was decided to be applied. The "Parking Lot Problem" was developed within the scope of a project conducted at Purdue University (Lesh \& English, 2017) and translated into Turkish, adapted and incorporated into the study by the research team. The data collection process was carried out as shown in Table 1 .

Table 1. Parking Lot Problem MEA: Data Collection Process

\begin{tabular}{|c|c|c|c|c|}
\hline & $\begin{array}{l}\text { Date } \\
\text { Work at home }\end{array}$ & Work at the class & Duration & Data collection tool \\
\hline $\begin{array}{l}\text { Week } 1 \\
\text { (February } 3 \text {, } \\
\text { 2020) }\end{array}$ & $\begin{array}{l}\text { - Giving the text / } \\
\text { introductory text } \\
\text { about the event } \\
\text { - Students are } \\
\text { expected to read }\end{array}$ & $\begin{array}{l}\text { - Reading } \\
\text { comprehension/ } \\
\text { answering } \\
\text { preparatory questions }\end{array}$ & $\begin{array}{l}1 \text { lesson hour } \\
\text { (40 min.) }\end{array}$ & $\begin{array}{l}\text { - Reading } \\
\text { comprehension/readiness } \\
\text { test on the MEA } \\
\text { - Observation form }\end{array}$ \\
\hline $\begin{array}{l}\text { Week } 2 \\
\text { (February 10, } \\
2020)\end{array}$ & $\begin{array}{l}\text { - Research required } \\
\text { for preliminary } \\
\text { preparation } \\
\text { - A preliminary } \\
\text { investigation can be } \\
\text { made on existing } \\
\text { parking } \\
\text { arrangements. } \\
\text { - They will have done } \\
\text { preliminary research } \\
\text { on the dimensions of } \\
\text { the vehicles that can } \\
\text { be parked. } \\
\text { - They are expected } \\
\text { to notice situations } \\
\text { such as opening the } \\
\text { vehicle doors easily } \\
\text { and being } \\
\text { comfortable. }\end{array}$ & $\begin{array}{l}\text { - They try to bring } \\
\text { together their } \\
\text { research as a group } \\
\text { and turn them into a } \\
\text { single answer. } \\
\text { - They are expected } \\
\text { to form a common } \\
\text { answer. Therefore, } \\
\text { students need/are } \\
\text { expected to } \\
\text { synthesize and } \\
\text { discuss the } \\
\text { information they have } \\
\text { obtained from their } \\
\text { research. }\end{array}$ & $\begin{array}{l}1 \text { lesson hour } \\
\text { (40 min.) }\end{array}$ & $\begin{array}{l}\text { - Observation form } \\
\text { - Voice recording } \\
\text { - Research Logbook }\end{array}$ \\
\hline $\begin{array}{l}\text { Week } 3 \\
\text { (Implementation } \\
\text { week) } \\
\text { (February } 17, \\
2020 \text { ) }\end{array}$ & $\begin{array}{l}\text { - They will have } \\
\text { made observations } \\
\text { and research. }\end{array}$ & $\begin{array}{l}\text { - The main problem } \\
\text { is given to the } \\
\text { students: How would } \\
\text { you help Burak } \\
\text { design his land in a } \\
\text { way to turn it into a } \\
\text { parking lot? }\end{array}$ & $\begin{array}{l}90 \text { mins } \\
(2 \text { lesson } \\
\text { hours and one } \\
\text { break) }\end{array}$ & $\begin{array}{l}\text { - Video and audio } \\
\text { records (For both } \\
\text { groups) } \\
\text { - Observation form }\end{array}$ \\
\hline
\end{tabular}




\begin{tabular}{|c|c|c|c|c|}
\hline $\begin{array}{l}\text { Week } 4 \\
\text { (February 24, } \\
\text { 2020) }\end{array}$ & $\begin{array}{l}\text { - Preparation of } \\
\text { banners, posters, } \\
\text { reports, letters, } \\
\text { models, } \\
\text { presentations, and the } \\
\text { like. }\end{array}$ & $\begin{array}{l}\text { Presentation and } \\
\text { reporting }\end{array}$ & $\begin{array}{l}2 \text { lesson hours } \\
\text { (80 mins) } \\
(\sim 15 \text { mins for } \\
\text { five } \\
\text { presentations })\end{array}$ & $\begin{array}{l}\text { - Poster, Model } \\
\text { - Evaluation form } \\
\text { - Presentation evaluation } \\
\text { form (Final verdict on } \\
\text { their own products) }\end{array}$ \\
\hline $\begin{array}{l}\text { Week } 5 \\
\text { (February } 28 \text { - } \\
\text { March 13, } \\
\text { 2020) }\end{array}$ & & & Out of class & $\begin{array}{l}\text { - Interview Protocol } \\
\text { (Conducting one-to-one } \\
\text { interviews and group } \\
\text { meetings) }\end{array}$ \\
\hline
\end{tabular}

In this study, the researcher tried to provide reliability by making detailed explanations at all stages, such as determination of the participants, data collection process, data analysis, and presentation of all attachments. Besides these, due to the difficulty of observing all groups simultaneously and ensuring that students in each group regularly attend school throughout the study, we focused on data from only two groups although we applied the study to the whole class. The research findings are limited to an interdisciplinary model eliciting activity conducted at the 8th-grade level within the theoretical context of the relevant literature review.

\section{Data Analysis}

Analysis of data obtained in a case study depends on the detailed description of the situation and the environment (Creswell, 2018, p.199). For this reason, data analysis was first started by describing the setting and explaining how the MEA was progressing. The data obtained from the MEA, student reports, documents, observations, and interviews were analyzed and interpreted using the descriptive analysis method. For this purpose, the data obtained was first described systematically and clearly.Then these descriptions were explained and interpreted, and cause and effect relationships were examined. Finally, some results were obtained. The descriptive analysis consists of 4 stages: (1) Creating a framework for descriptive analysis (2) processing the data according to the thematic framework (3) defining the findings and (4) interpreting the findings (Yıldırım \& Şimşek, 2011). For this purpose, the in-class modeling activities, student reports, and documents of the two groups of 8th-grade students were analyzed using the modeling process developed by Blum and Borromeo Ferri (2009) as given in Figure 1. 
Four steps to solve a modelling task ("Solution Plan")

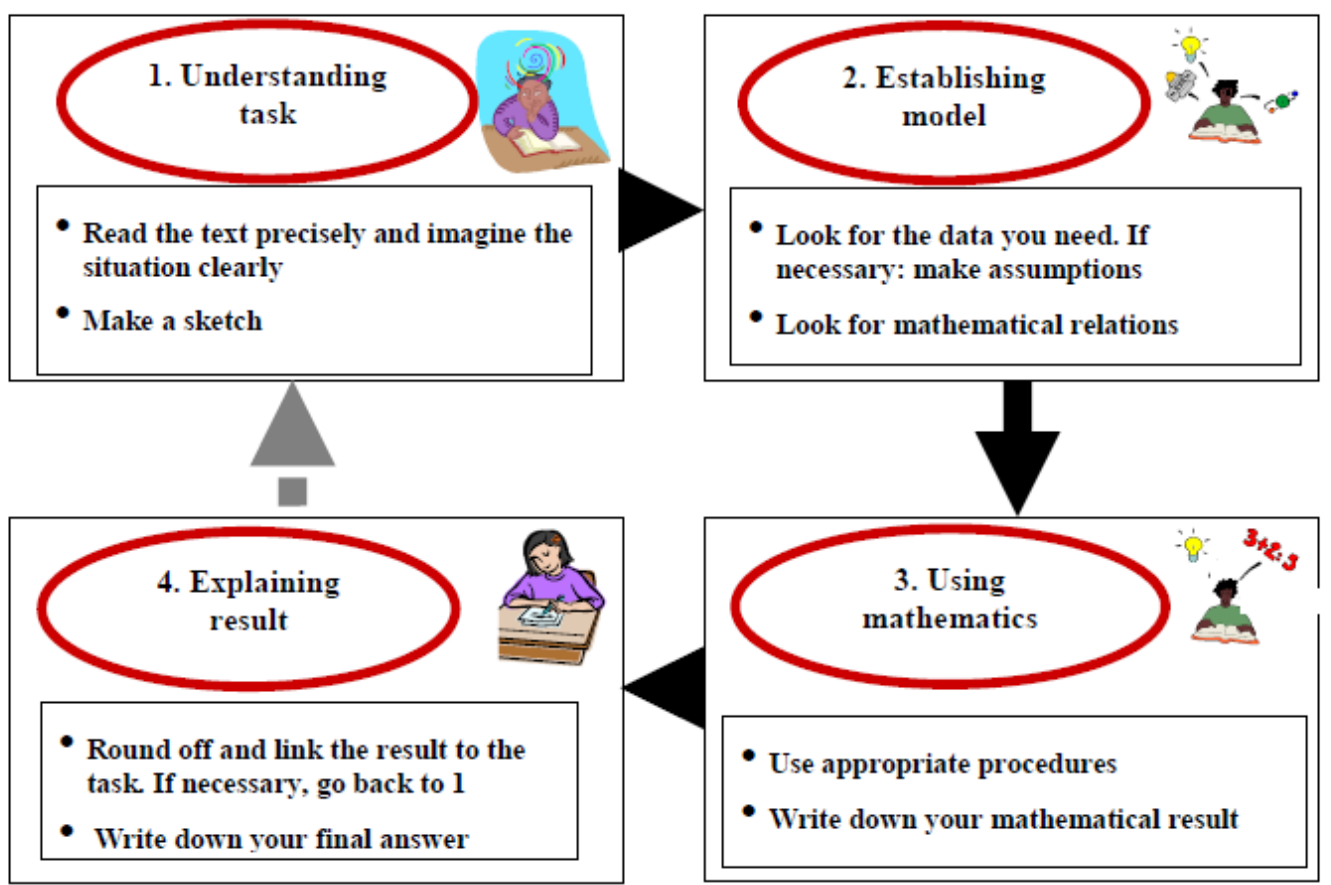

Figure 1. Solution Plan for Modeling Tasks (Blum \& Borromeo Ferri, 2009)

This process consists of four stages: understanding the problem, establishing a model, using mathematics, and explaining the result. During the data analysis, each group's modeling process was examined, the stages the groups passed through in the model-eliciting process were determined in order, and the difficulties they encountered in these stages were revealed. The findings were supported with direct quotations from one-to-one and group interviews.

\section{Findings}

\section{Group A - MEA General Process: Parking Lot Problem}

The introductory text about the Parking Lot Problem was given to the groups in the first week. The students read and discussed the problem text individually and in groups, and three students explained what they understood from the text to the class. Afterwards, each group answered their reading comprehension/warm-up questions. Some answers belonging to group A are shown in Figure 1. 


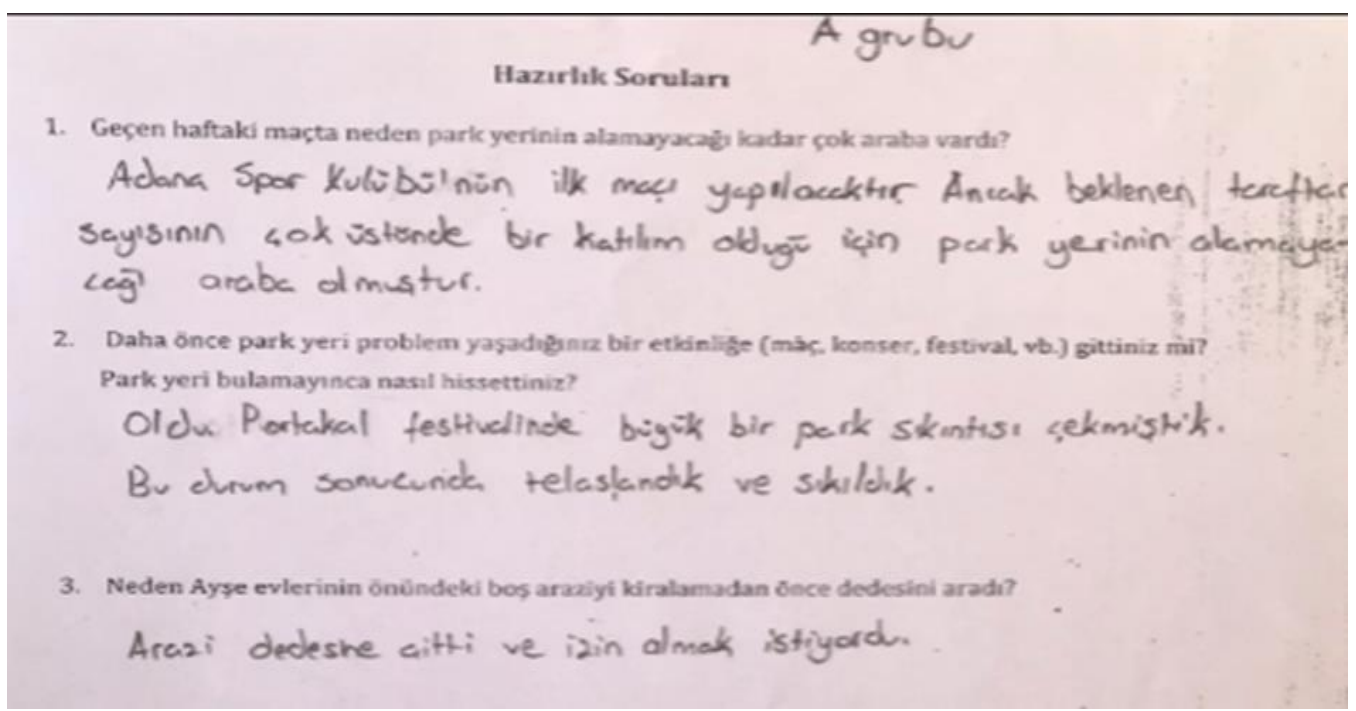

Figure 2. A Cross-Section of Group A's Answers to the Warm-up Questions of the Parking Lot Problem

It was observed from the answers they gave to the warm up questions that Group A understood the introductory text, determined what data they should research or observe for the 2 nd week, and started to distribute the tasks within the group.

The first week was completed in one class hour. At the end of this lesson, Group A and B were given activity files prepared by the research team and a research logbook and blank papers students they would note their observation and research for the Parking Lot Problem until the second week. . In the second week, each group presented their research and observations to the class and engaged in dicussions. A section from the research logbook belonging to Group A is shown in Figure 3. 


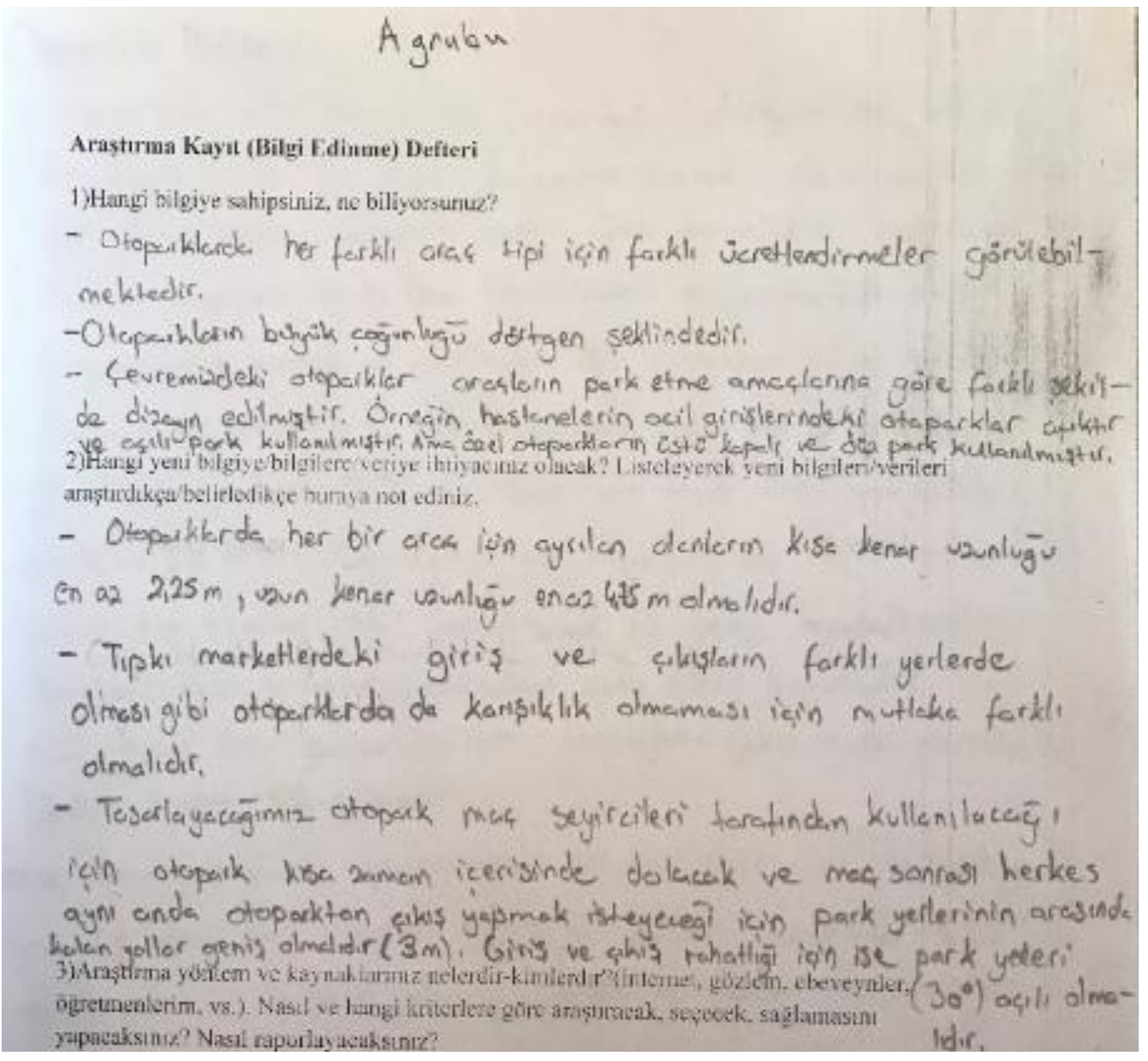

Figure 3. A Snapshot of Group A's Research Logbook on the Parking Lot Problem

According to the data obtained from Group A's research logbook and the in-class observations, Group A did good preliminary research, and they carried out their observations and research in a collaborative group. They tried to determine which variables were the priority for the parking lot design. Although the problem text had not been given yet, they researched about some assumptions needed for problem-solving.

The 2nd week lasted 1 lesson hour, and the lesson was completed by giving each group the list of materials they could use for the 3rd week.

\section{Group A- Model Eliciting Process}

In the third week, the students were present with the materials included in the material list given to them in the second week and worked as a group. The clasroom seating arrangement for the Parking Lot Problem in the 3rd-week is shown in Figure 4. 


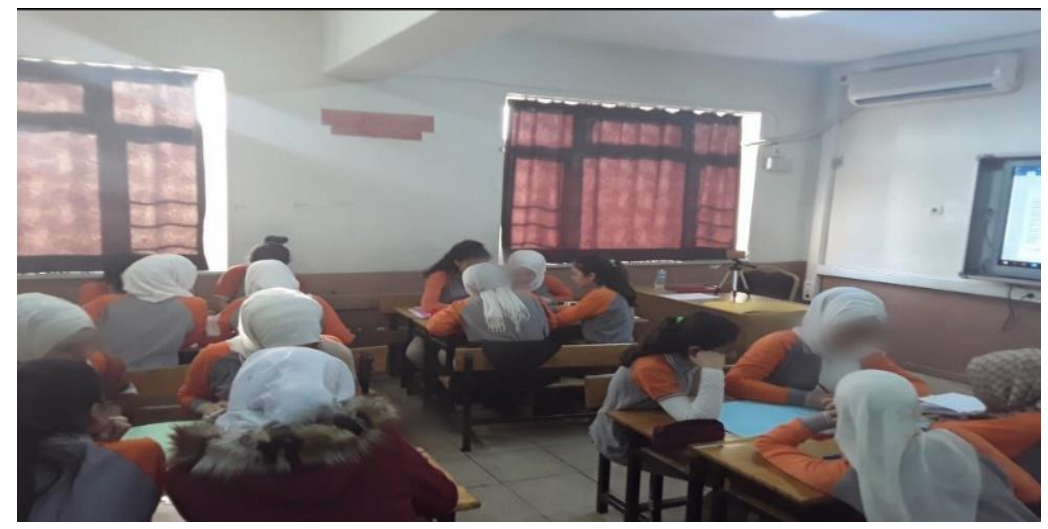

Figure 4. Classroom Seating Plan During the Parking Lot Problem MEA

The third week started with each group being given the problem text (their task) and background cardboards with the outline of the land. A voluntary student from the class read the problem text to the class, and Asli from the Group A told the class what she understood from the problem text. The application took 90 minutes (2 lesson hours and one break). The stages of how Group A followed the modeling process are given in Table 2.

Table 2. Parking Lot Problem MEA: Modeling Process of Group A Group A - Parking Lot Problem

\begin{tabular}{|c|c|c|c|}
\hline $\begin{array}{l}\text { Understanding the } \\
\text { Problem }\end{array}$ & Establishing a Model & Using Mathematics & Explaining the Results \\
\hline $\begin{array}{l}\text { It took some time for } \\
\text { Group A to understand } \\
\text { what was asked of them } \\
\text { in the parking lot } \\
\text { problem. They argued } \\
\text { that the entrance and } \\
\text { exit of the car park } \\
\text { were from the same } \\
\text { spot and that they } \\
\text { should not change } \\
\text { them. Then, assuming } \\
\text { that it is important for } \\
\text { the vehicles to make } \\
\text { their entrance and exit } \\
\text { comfortably, they } \\
\text { started to create their } \\
\text { designs. }\end{array}$ & $\begin{array}{l}\text { After deciding the } \\
\text { entrance and exit } \\
\text { directions of the } \\
\text { vehicles and the length } \\
\text { of the car park entrance } \\
\text { and exit, they } \\
\text { determined the width } \\
\text { and length for each } \\
\text { parking lot. They used } \\
\text { their preliminary } \\
\text { research to make a } \\
\text { decision on this issue. } \\
\text { Since they assumed that } \\
\text { the entrance and exit } \\
\text { should be comfortable, } \\
\text { they chose to draw the } \\
\text { parking lots at an angle } \\
\text { of } 60^{\circ} \text {. }\end{array}$ & $\begin{array}{l}\text { They started to draw } \\
\text { parking lot models using a } \\
\text { protractor and ruler. While } \\
\text { making these drawings, } \\
\text { they took into account the } \\
\text { measurements they } \\
\text { obtained in their } \\
\text { preliminary research. They } \\
\text { measured the width and } \\
\text { height of the four vehicle } \\
\text { models given in the } \\
\text { problem text. Considering } \\
\text { the length of the vehicle } \\
\text { doors when they were } \\
\text { open, which they } \\
\text { determined in their } \\
\text { preliminary research and } \\
\text { observations, they } \\
\text { calculated the average } \\
\text { values and continued to } \\
\text { draw their designs again. }\end{array}$ & $\begin{array}{l}\text { Group A reviewed their } \\
\text { completed designs, } \\
\text { prepared their results, and } \\
\text { wrote their reports. They } \\
\text { stated that the model they } \\
\text { created was mostly } \\
\text { correct, but there might } \\
\text { be a number of } \\
\text { shortcomings. }\end{array}$ \\
\hline
\end{tabular}

After reading the problem text, Group A started to argue about some assumptions by expressing their individual opinions. In particular, they made assumptions such as making the entrance and exit of the car park from the short side of the rectangle or opening another door for exit. They discussed about changing the measures they had determined in their preliminary preparations. During this process, they frequently asked questions to the teacher. It can be said that they did not fully understand the problem. It can also be said that they passed the stage of the establishing a model without fully understanding the problem. From this stage, they returned to the stage of understanding the problem and reviewed the problem again. After reviewing the problem, they 
measured the dimensions of 4 vehicles, scaled down by 1:100 in the problem text: SUV (Jeep) $1.90 \mathrm{~cm}$ x $4.75 \mathrm{~cm}$, sedan $1.80 \mathrm{~cm}$ x $4.75 \mathrm{~cm}$, hatchback $1.60 \mathrm{~cm}$ x $3.90 \mathrm{~cm}$ and van style 1.60 $\mathrm{cm} \times 4.50 \mathrm{~cm}$. After the measurements, they tried to determine the average values with the vehicle dimensions in their preliminary research. At the same time, they decided to draw at an angle of $60^{\circ}$ assuming that the ease of entry and exit of vehicles is very important in parking lot designs. In group and one-to-one interviews, they also made explanations supporting these thoughts:

Aslı: The first solution that came to our mind was that there should be no disruptionor trouble as the vehicles move through the parking lot. So, for example, the area gets narrower when making wturns, so we took turns a little wider; we made a round, circular turns instead of a 90 degree turns, we paid attention to it. In other words, our first goal was to ensure that the vehicles could move freely of course; we gave importance to comfort the most; we thought that the others would come after the comfort.

Melek: We tried to make it so that cars move more comfortably, and problems are solved without arguing or fighting. There is always some tension on match days when supporters of different teams come together. When we designed it at a proper angle, there were more parking spaces, and it was easy to enter and exit. What we noticed in our research was that $30^{\circ}$ isused more commonly, because it is more comfortable while coming out, such as when turning or exiting ...

Aysel: We did something for them to enter and exit comfortably, Sir, because we made it with an angle, so that they could both enter and turn easily, if we had made it straight, it could have been be quite a thing, and because we left a lot of distance [the corridor], two cars could go.

Nevin: We designed it mostly according to the length of our entrance angle, what was it called?, how to come out more comfortably; we left a lot of angles since the space is narrow, the entrance and exit should be comfortable.

Before passing to the drawings, they calculated the width and length of the vehicle parking lots with the data they obtained from the preliminary research and observations. They started drawing by determining the entrance and exit directions of the vehicles on the land draft and using the angle meter and ruler. With the data they obtained from their preliminary research, they decided to design two types of parking spaces by adding the average of the measurements given in the problem text and the approximate distance when the doors of the vehicles were opened. The results of these stages, which we can describe as the stage of using mathematics, are indicated in the students' worksheets as shown in Figure 5.

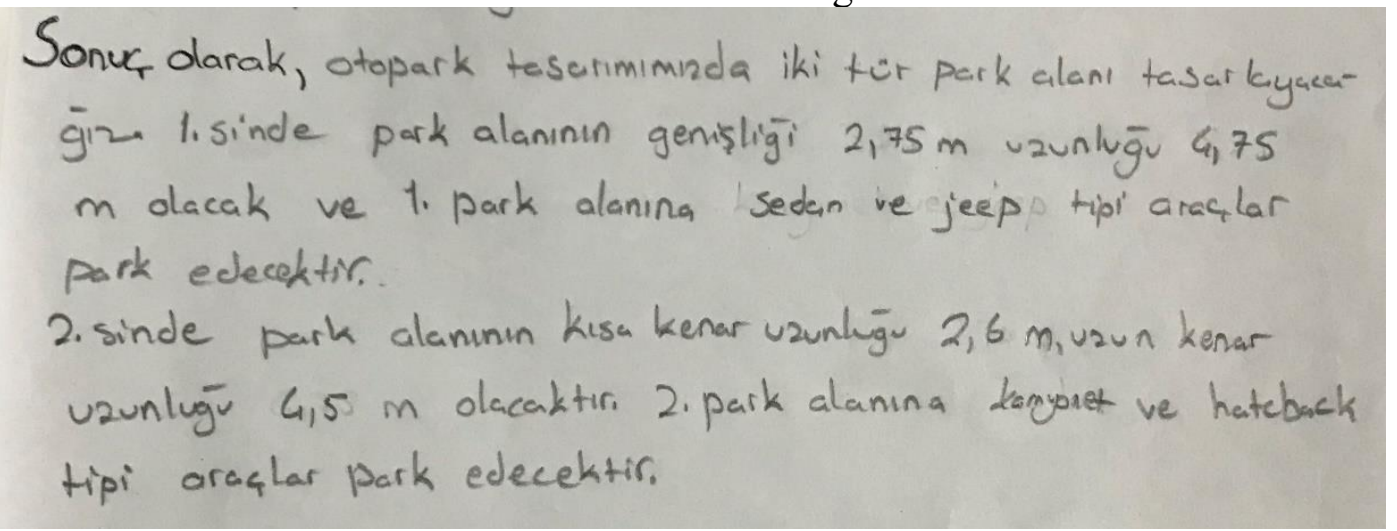

Figure 5. A Cross Section from the Stage of Using Mathematics for Group A's Parking Lot Problem 
Figure 6 shows the dimensions of the two types of vehicle parking lot, determined by Group A by taking the averages, and the draft drawings of the vehicle parking lots drawn at an angle of $60^{\circ}$.

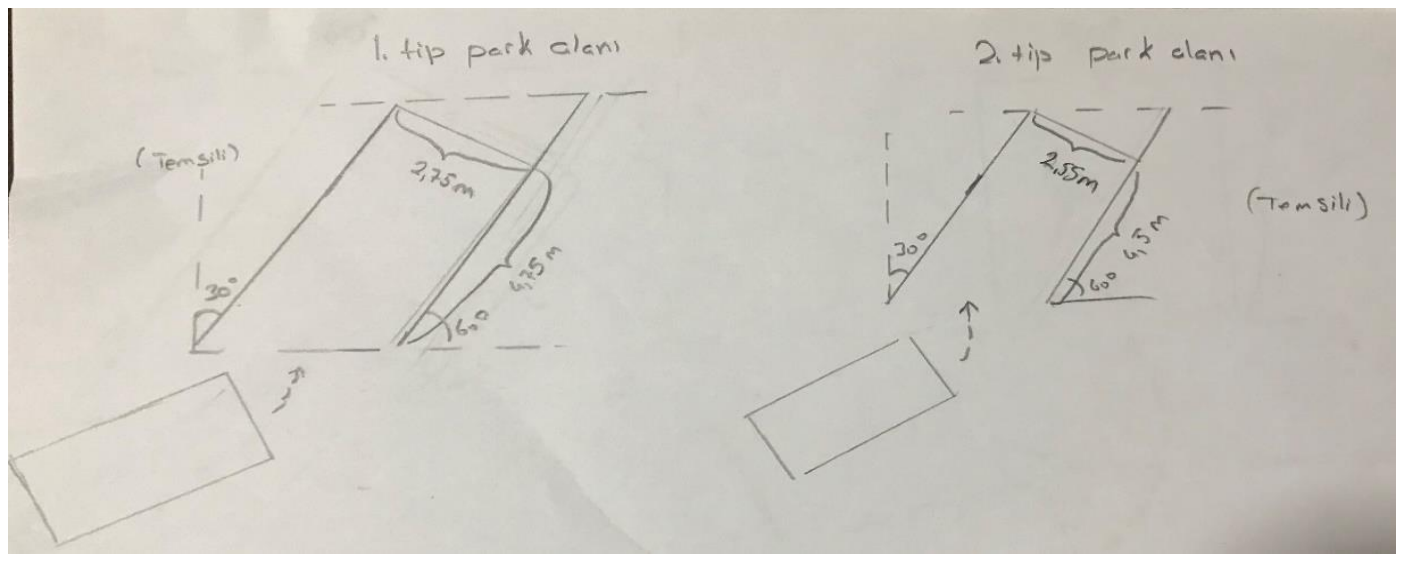

Figure 6. Another Part of Group A's Parking Lot Problem at the stage of Using Mathematics

Although Group A could draw their parking spaces at $60^{\circ}$, they lost much time. Each group member was willing to draw, but they argued when mistakes were made in the drawings. The group members who argued redistributed the task by dividing the drawing work. From here, it was determined that the members of Group A were willing to use protractors and rulers. They were confident in themselves and warned each other when they realized their mistakes. However, as a group, they made some measurement and drawing mistakes in their designs. Therefore, it can be said that the participants did not have enough understanding of some geometry concepts such as angles, angle drawings, lengths, and quadrilaterals to use some tools such as protractors and rulers. , Even if students have an understanging of these to a certain degree, they need more experience in these areas.

During one lesson in the fourth week, all groups presented the designs/models they had formed to other groups. Group reports/letters were also presented this week, which was the stage of explaining the results. Images from the presentation of Group A are shown in Figure 7.
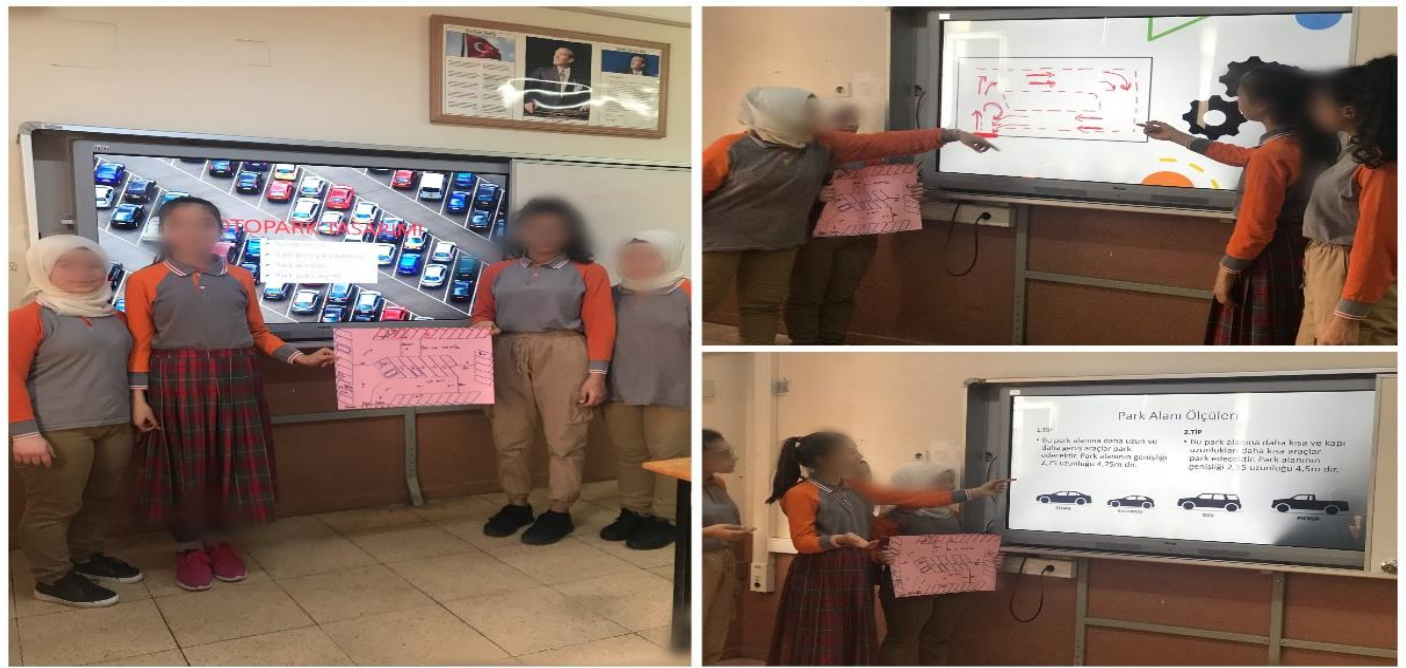

Figure 7. Group A's Presentation of the Parking Lot Problem / Details of the Results from the Explanation Stage

After the phase of presentation and explanation of the results, the participants evaluated their 
groups and the other two groups they specified. During the interviews with Group A, the participants stated their opinions about the parking lot design that they had created as follows:

Aslı: Well, we can pass it on, we can review the proportions, because I thought of reducing the lengths by $5 \mathrm{~cm}$ and the width of the parking areas by $5 \mathrm{~cm}$, because the difference was very little between the first type and the second type. It was $20 \mathrm{~cm}$ only in width. We thought of doing it, because I said that everyone would focus on the 2nd type, the van type, and the hatchback type, as they cost less. We thought of opening the difference for $5 \mathrm{~cm}$ more for each in width. We thought of opening up between them; for example, 2.55 would be 2.50 instead of the other one which would stay 2.75 , then more cars would fit, and not everyone would concentrate on Type 2 . The price of Type 2 would be low; although they could not fit, they might try to enter Type 2 , and maving only one type does not make sense to me.

Melek: I think it is true; I think Burak would choose us. Because the other friends of mine had a tighter entrance and exit, they had taken the corridors very short, and sometimes the cars were directly [leaving]. Fifty-one cars fit in our space, I guess my other friends also had 54 ones, but theirs was not very comfortable. Our model was correct, $80 \%$ or so.

Aysel: For example, we could fit more cars, there was already free space left, yes, but it was good, it was good in general.

Nevin: We think it was correct; it was $75 \%$ correct. What we were lacking, we could fit more tools; we could fit 50 or something. I think we gave great importance to comfort, and we may have given the angle a little too much. The one who used the car would park anyway.

As can be seen from the explanations above, Group A generally thought that the design they created was correct but had some deficiencies. They expressed different opinions about these shortcomings.

\section{Group B - General Process of the Parking Lot Problem MEA}

Group B followed the initial stage in the modeling process the same way as Group A. The introductory text about the Parking Lot Problem was given. Three students who were willing explained what they understood from the text. Then, they passed to reading comprehension/warm-up questions. Some of the answers from Group B are shown in Figure 8 below: 
5. Siz olsanız nasıl fiyatlandırırdınız? Farklı türdeki araçlar için farklı fiyatlar verir miydiz?

Araçtaki kişi başına farklı fiyatlandırma uygular mıydınız? Açıklayınız.

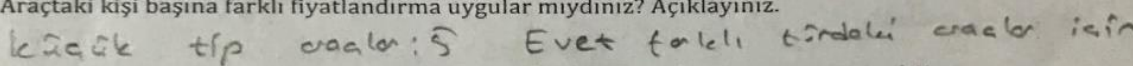

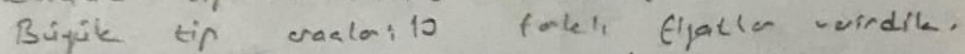

Sadece raa pok edilicegi iain kigi basina fobli fiygt

6. Neden Ayșe'nin park yeri taslağı oluștururken farklı türdeki araçların olacağını düşünmesi ge-

rekti?

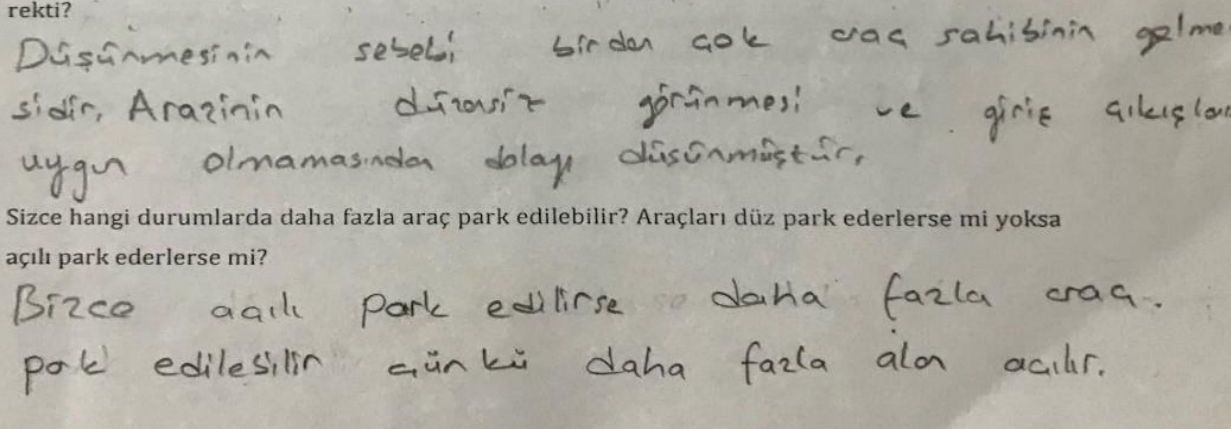

Figure 8. A Section of the Answers given by Group B to the Warm-Up Questions of the Parking Lot Problem

It can be said from the answers given to the warm-up questions that they understood the introductory text. However, they did not distribute the group member's tasks for the second week, according to researchers' observations. They could not determine which observations and researches they should do to answer the questions in the distributed research log. A section from the research logbook belonging to Group B is shown in Figure 9.

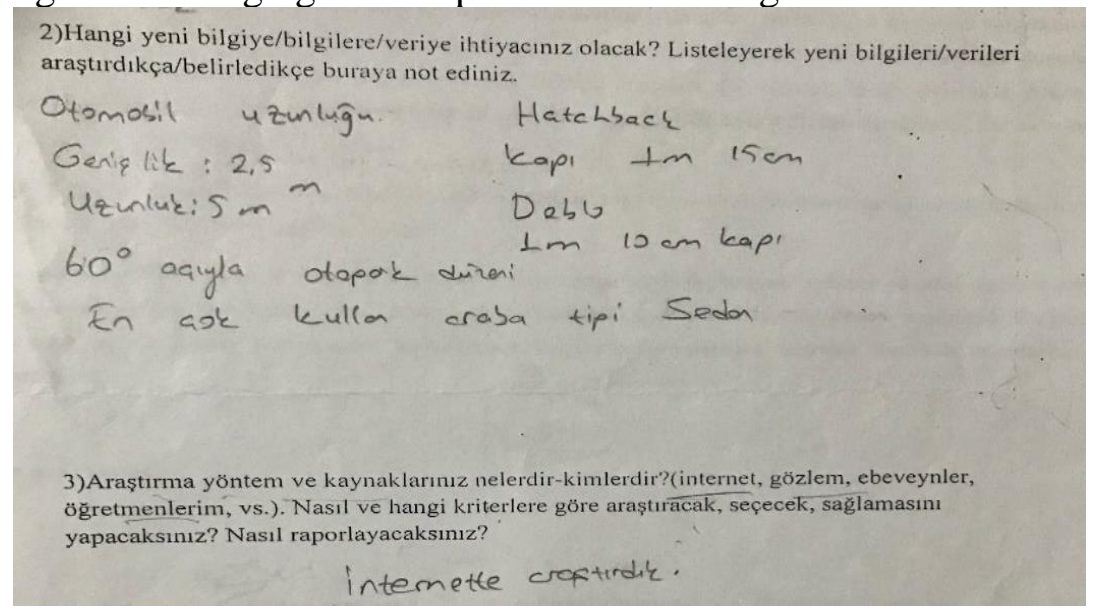

Figure 9. A Section from the Research Logbook of Group B Regarding the Parking Lot Problem

According to the research logbook, Group B did insufficient research; each group member had access to some data from the internet instead of making measurements and observations from daily life. In addition, according to the observations, the students of Group B conducted their research individually, not as a group, and they wanted to work individually instead of creating a common research logbook. 


\section{Group B- Model Eliciting Process}

In the 3rd week (practice week), Group B was present with their materials and group seating. A view from the seating arrangement of Group B in the 3rd week is given in Figure 10.

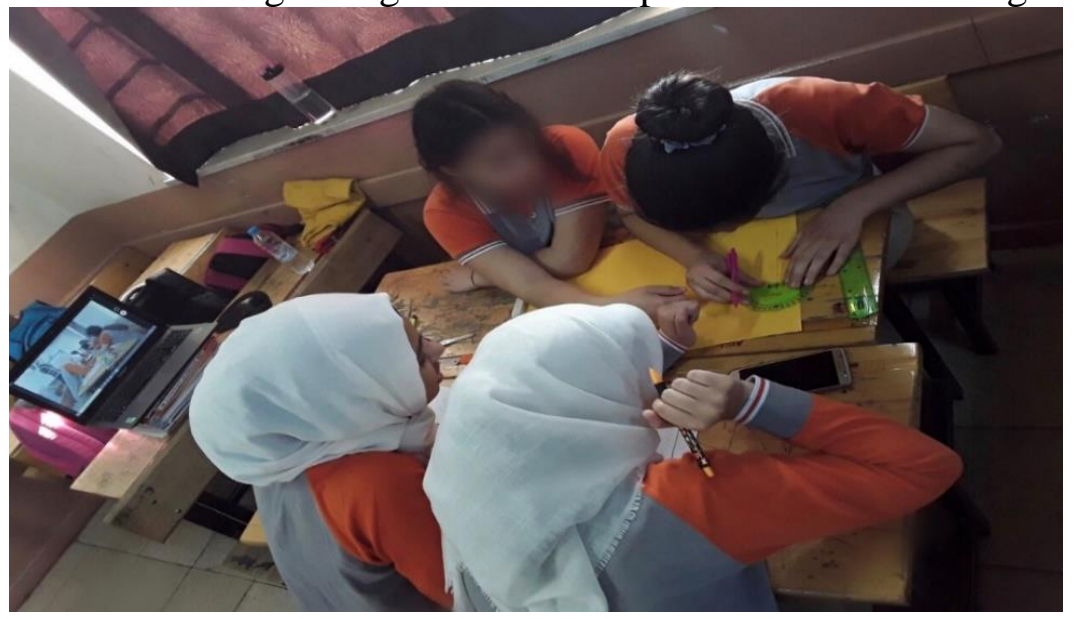

Figure 10. Group B, Parking Lot Problem, 3rd Week Seating View

It was observed that some members of Group B were eagerly awaiting the problem text. Still, the group's communication and interaction were weak due to the insufficient and incomplete studies carried out in the first and second weeks. How Group B followed the stages of the modeling process is given in Table 3.

Table 3. Parking Lot Problem MEA: Modeling Process of Group B

\begin{tabular}{|c|c|c|c|}
\hline \multicolumn{4}{|c|}{ Group B - Parking Lot Problem } \\
\hline $\begin{array}{l}\text { Understanding the } \\
\text { Problem }\end{array}$ & Establishing a Model & Using Mathematics & Explaining the Result \\
\hline $\begin{array}{l}\text { After reading the } \\
\text { problem text, Group B } \\
\text { discussed how to make } \\
\text { their drawing after } \\
\text { being given the land } \\
\text { drafts. They read the } \\
\text { problem as a group and } \\
\text { did not discuss what } \\
\text { was delivered. Since } \\
\text { they did not fully } \\
\text { understand the } \\
\text { problem, they started to } \\
\text { discuss in which parts } \\
\text { to draw areas, such as } \\
\text { the disabled vehicle } \\
\text { spots, the pool and the } \\
\text { flower bed. }\end{array}$ & $\begin{array}{l}\text { Instead of initially } \\
\text { determining the } \\
\text { necessary data/variables } \\
\text { to solve the problem, } \\
\text { they decided to draw the } \\
\text { parking areas at an angle } \\
\text { of } 60^{\circ} \text {. They spent about } \\
\text { one-third of their } 90- \\
\text { minute time trying to } \\
\text { draw parking areas with } \\
\text { an angle of } 60^{\circ} \text {, and } \\
\text { when they had difficulty } \\
\text { drawing, they decided to } \\
\text { draw it straight }\left(90^{\circ}\right) \text {. }\end{array}$ & $\begin{array}{l}\text { They made drawing } \\
\text { exercises at an angle of } 60^{\circ} \\
\text { using a protractor and ruler. } \\
\text { They determined the } \\
\text { parking lot dimensions with } \\
\text { their preliminary research } \\
\text { and observations without } \\
\text { measuring the dimensions of } \\
\text { the vehicle types given in } \\
\text { the problem text. They } \\
\text { determined the car parking } \\
\text { areas' dimensions as } \\
\text { uniform and rectangles of } 3 \\
\mathrm{~cm} x 5 \mathrm{~cm} \text {. }\end{array}$ & $\begin{array}{l}\text { Group B reviewed the } \\
\text { draft/model they } \\
\text { created and wrote a } \\
\text { report. They stated that } \\
\text { they had shortcomings } \\
\text { in their models and that } \\
\text { their preliminary } \\
\text { research was } \\
\text { insufficient. In the first } \\
\text { three weeks, they did } \\
\text { not divide the work as a } \\
\text { group and wanted to } \\
\text { work individually, and } \\
\text { in the presentation } \\
\text { week, they announced } \\
\text { their results in } \\
\text { cooperation. }\end{array}$ \\
\hline
\end{tabular}

After reading the problem text, Group B started to discuss about some assumptions by expressing their individual opinions. They began to examine the notes in their preliminary research. Later, they thought of designing the land model as an accessible parking area, pool, flower area, and parking areas. It can be said that they do not fully understand the problem. They tried to move to the modeling stage without understanding the problem adequately and to complete the modeling stage without determining the basic variables and the data required for the solution. As a result of their preliminary research, they determined a parking area for about 
a single type of vehicle without sufficiently thinking and making measurements about the four vehicle models, whose dimensions were scaled by 1:100, given in the problem text They determined the dimensions of these areas as rectangles with a short side of $3 \mathrm{~cm}$ and a long side of $5 \mathrm{~cm}$. They decided to draw at $60^{\circ}$ angles. In this process, they wanted to act individually. In the stage of using mathematics, they tried to draw $60^{\circ}$ parking areas by using a protractor and ruler; although they used approximately 30 minutes of the 90 -minute practice time, they could not draw. In group and one-to-one interviews, they also made some explanations supporting this finding:

Sude: We said we should draw the first oblique, we noted that it should be angled at 60 degrees, we decided that, when we got the thing in front of us, we could not draw the rectangular thing [land model], we struggled we could not draw it, then we decided to make it straight, that is $90^{\circ}$. We said, let us draw at an angle of $60^{\circ}$, we drew it at home, but it did not helped us at all when we came to school. We could not draw.

Rana: We first thought of a $60^{\circ}$ angle, I drew it at home, but when we came to school, we could not do it. Then we made it at $90^{\circ}$ when we could not draw. So it would be a beautiful thing if we could draw, but we could not.

Figen: But we could not draw at an angle; we also lost time, then drew it straight. We would do it at 60 degrees, but we could not do it; we could not draw. We could not do it because it was not proper.

Nilay: We kept trying with no results, it was the last 10 minutes (to the end of the first lesson), then Sude said, let us do it with $90^{\circ}$ because there was nothing left to do. We had a hard time with her while drawing.

Group B also stated the following explanation about the accuracy of the parking lot draft they created:

Sude: Actually, it was necessary because we did not fully arrange the entrance and exit of the cars, how they would go, lengths, dimensions, exits, and so on. We also took a width of more than 3 meters. It would be better if it were 2.70 meters or so. At least we could fit more vehicles.

Rana: [...] I mean, it did not work as I wanted it. If I could draw, then I would be sure. I think it would have been 54 or something if we had drawn it with a 60-degree angle.

Figen: We thought the cars were few; we thought we could fit a few more [...]

Nilay: We did many things, Sir, we made the widths wide, because everybody is ours; I think there are 51 things in the second order, the most? It was 53.

Based on the statements above, it can be concluded that Group B was not sure about the parking lot model they formed and they had problems and deficiencies at some stages. It was observed that in the presentation week (week 4), which is the stage of explaining the results, Group B worked in cooperation, and other group members who were not active in the other stages took an active role. A view from Group B in the presentation week is shown in Figure 11. 


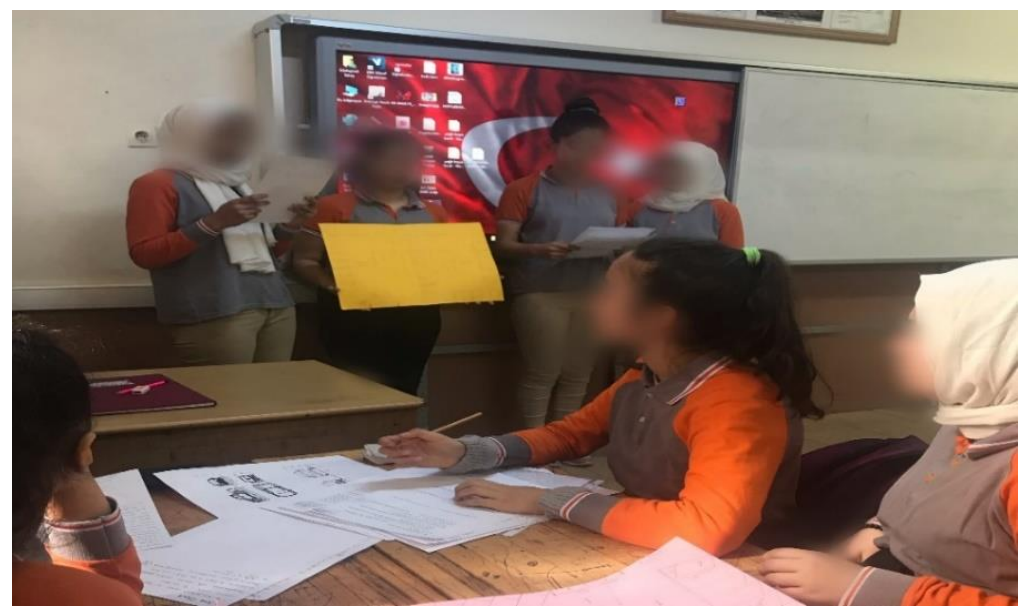

Figure 11. Group B, Parking Lot Problem Presentation / A View from the Stage of Explaining the Results

Group B had a problem working collaboratively and distributing the tasks as a group during the first three weeks. Therefore, they did not want to listen to each other's opinions. However, in the 4th week, they explained the results by distributing the tasks, and they were able to learn to work in cooperation. However, Group B stated that the parking lot design they made was correct at the end of the presentation, but they should have reviewed some of their measurements and calculations.

\section{Comparison of Group A and B and the Difficulties The Faced During the MEA}

The Parking Lot Problem was applied to groups A and B and the class in the education process. The group members' modeling processes through mathematical thinking and writing processes were examined, and quotations from one-to-one and group interviews were included. Both groups had problems in understanding the problem, which is the first step of problemsolving. However, Group A tried to overcome this problem by discussing it as a group and asking questions to the teacher frequently. Group A, which prioritized the drivers' convenience, discussed the assumptions such as the entrance and exit of the parking lot being in different places, the entrance and exit of the parking lot being on the short side of the rectangle and the parking lot being at an angle of $60^{\circ}$, and they wanted to move to the modeling stage without understanding the problem sufficiently. Although Group B had difficulties understanding the problem, they did not read and discuss the problem as a group. Since they tried to read and understand the problem individually, it took longer to overcome this problem compared to Group A.

During the phase of establishing a model, Group A discussed the relevant data for the solution of the problem and was able to identify mathematical relationships. Both Group A and B tried to determine the dimensions of the parking spaces with their preliminary research without measuring the dimensions of the four different vehicle types given in the problem text. By asking frequent questions to the researcher, Group A understood that they had to measure the dimensions of four different vehicle types, scaled-down by a ratio of 1:100. Using preliminary research and observations, they estimated the opening distance of a door as approximately 40 $\mathrm{cm}-50 \mathrm{~cm}$. Then, they decided to create two types of parking areas for the parking plan by adding the opening dimensions of the doors of the vehicles to the width of the vehicles. Group $\mathrm{B}$ tried to determine the necessary data and mathematical relationships to solve the problem, which is the modeling stage. After a while, they realized that they should measure the 
dimensions of four different vehicle types individually by asking questions to the researcher like Group A, rather than by discussing it as a group. Stating that their preliminary research and observations were lacking, they planned to design a uniform parking lot by considering the openning length of the car doors as approximately $60-80 \mathrm{~cm}$.

At the stage of using mathematics, students performed mathematical operations in Group A, determining approximate values. As a result, the measurements of the parking area types in the parking lot that they would create were $2.75 \mathrm{~cm} \mathrm{x} 4.75 \mathrm{~cm}$ for type 1 (for SUV and Sedans) and $2.60 \mathrm{~cm} \times 4.50 \mathrm{~cm}$ for type 2 (hatchback and van style). They also determined the approximate dimensions of the vehicles' exit distances (corridors) based on their preliminary research and observations. They determined the vehicles' directions and the entrance and exit door dimensions by measuring them with a ruler. They drew the parking spaces at $60^{\circ}$ angles using a protractor and ruler. This process was generally carried out as group work under the leadership of a student. Group B did not use mathematics much and determined the dimensions and measurements with approximate values without paying much attention compared to Group A. In the parking lot that they would create in the land draft, they determined the parking spaces for one type of vehicle as $3.00 \mathrm{~cm} \times 5.00 \mathrm{~cm}$, and they decided to draw the parking spaces at $60^{\circ}$ angles. They determined the car exit distance (corridor) as $8 \mathrm{~cm}$. Using a protractor and ruler, they tried to draw the parking lots at an angle of $60^{\circ}$. Although they used more than 30 minutes of the 90-minute application time, they could not draw. Realizing that their time was running out, they decided to draw the parking areas straight (at a $90^{\circ}$ angle). Group work was carried out poorly under the leadership of 2 students in this whole process.

At the stage of explaining the results, Group A reviewed the parking lot model they created and stated that they thought it was mostly correct and completed the process by writing a detailed report to the so-called client Burak, who asked for help for their lot design. Group A stated that they were very confident about their designs while making their presentations, and they did not have any deficiencies. However, after all presentations in the class were finished, they stated in the interviews that their designs also lacked the presentation evaluation form and that they made wrong assumptions and made some measurements and calculations inaccurately. Group B stated that they had too many deficiencies. From here, it can be said that in-group interaction, communication and discussion are important factors in MEAs both in the development of social interaction among groups and in the more successful execution of the modeling process. The final versions of the parking lot designs of Group A and Group B regarding the Parking Lot Problem are shown in Figure 15. 

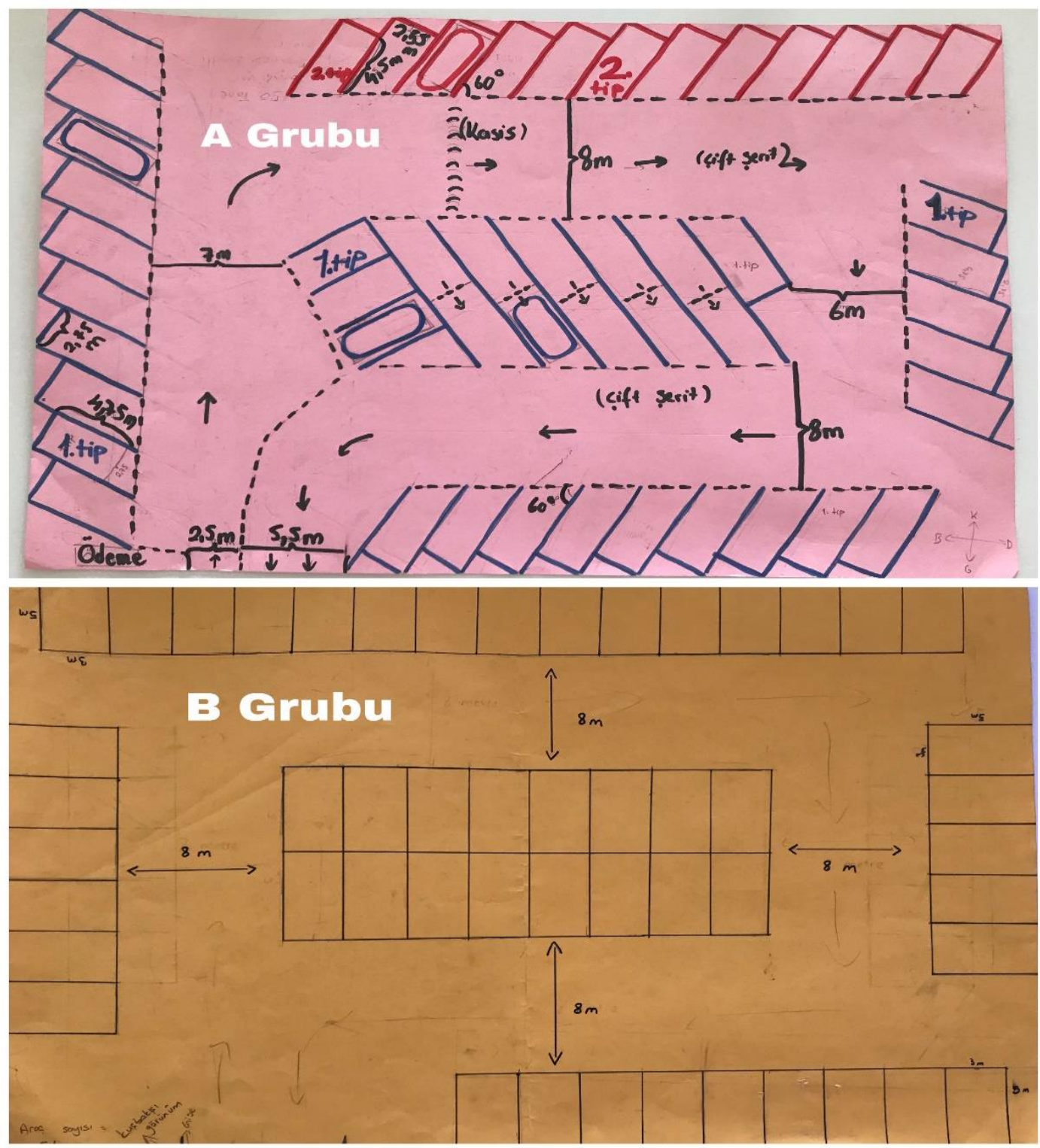

Figure 12. Parking Lot Designs of Group A and B

Findings obtained with observations and interviews during the modeling process revealed that 8th-grade students faced some difficulties. These difficulties were determined in 7 categories, including understanding the problem, establishing a model, using mathematics, explaining the result, - which are the four steps of the modeling process - working in a group, verifying the created model, and time management.

In understanding the problem, which is the first step of the modeling process, students had difficulty understanding the problem text in both activities. Although the students were asked to create the most parking space in the Parking Lot Problem activity, the students tried to design the parking area with different purposes (pool, accessible parking areas, a flower area, and the like), keeping the corridors wide with assumptions such as the comfortable entrance and exit of the vehicles, and they moved away from the main variable.

During the phase of establishing the model in the Parking Lot Problem activity, Group B wanted to move to the stage of using mathematics and draw without determining significant 
relationships such as determination of the measurements of 4 vehicle drafts given in the ratio of 1:1000, land entrance and exit being on the same spot, consideration of the openning distances of vehicle doors and determination of the width of the corridor. Group A tried to determine these relationships by managing this process more properly, but they frequently asked questions to the researcher in this process.

Group B could not draw $60^{\circ}$ parking areas using a compass and ruler at the stage of using mathematics, and then they decided to draw $90^{\circ}$ parking areas. In addition, they did not make any calculations to verify the model they created intuitively by associating it with daily life.

In the phase of explaining the result, both groups completed the activities by writing a letter/report to the so-called client. Before writing their reports, both groups reviewed the postimplementation models and made corrections.

They stated that they faced some difficulties working in a group although they emphasized in the interviews that it was always better. Below are quotations about group work from some of the members of Groups A and B during the MEA:

Aysel: Usually, we all agreed, but sometimes they did not want what I wanted, or I did not want what they wanted, we had a hard time reaching a consensus.

Sude: Because a friend says something, I am saying something else; this time, there is a little contrast. I say it is not one type; one says that it is one type, one offers another pricing, I offer another pricing. Therefore, there are some contrasts.

Figen: There were so many ideas, we were very hesitant. We were extremely indecisive.

Nilay: You know, we had a bit of trouble, they did not let us do it at first, so we had some trouble, but there are good things about working together.

As can be understood from the quotations above, some students did not listen to the opinions of other group members during the group work process and wanted to work individually or in pairs. In addition, another situation experienced during group work was that while a student in the group came to the fore and guided, the others made very limited contribution to the discussions and instead, preferred to listen. However, some students tried to make individual decisions rather than discussing with each other and reaching an agreement at the stages of the modeling process.

The students had difficulty verifying the created model in the MEA. Instead of verifying the model based on observation, research, measurement, and calculations, they wanted to prove it by associating it with daily life although it was usually intuitive.

The groups also had difficulties in terms of time management during the modeling process. Although 90 minutes were given during the implementation process ( 3 rd week), they could not finish their designs/models and completed the process with some shortcomings in the last minutes. They completed the task of writing reports/letters and explaining results in the next week (4th week) apart from this implementation period. In this respect, it appears that middle school students need multiple MEA applications to be more experienced in model building processes and to overcome these difficulties.

From here, it can be said that in-group interaction, communication, and discussion in MEAs are important factors both in the development of social interaction of groups and in the more successful execution of the modeling process. 


\section{Discussion and Conclusion}

The findings obtained in this study provide important information about the modeling processes of middle school 8th-grade students in modeling activities. The Parking Lot Problem, an interdisciplinary MEA, was applied to two groups of four, consisting of middle school 8thgrade students. The modeling processes they put forward were examined qualitatively. In this whole process, students in both groups were involved in many thinking processes, where the existing situation/problem text was reviewed from time to time.

The students produced many new and different ideas and discussed various assumptions until reaching a conclusion. In other words, the Parking Lot Problem MEA created a different learning environment for students by creating an opportunity for them to think deeply, reveal and develop mathematical ideas, and revise and organize these ideas. In this respect, it can be said that in the Parking Lot Problem modeling activity, as Balakrishnan et al. (2010) stated in their studies, students were allowed to find a solution to a real-life problem, unlike traditional problems, and to see how daily life problems can be solved with the help of mathematics. Besides, in the Parking Lot Problem, Swan et al. (2007) stated that students used many mathematical skills, mathematical language, and tools. They understood that mathematics is related to engineering and other disciplines and saw that it is used within life.

The students wanted to move on to other stages without understanding and interpreting what was given in the problem. As a result, they repeatedly returned to the problem text, making wrong assumptions and calculations. Similarly, Sol et al. (2011), Blum and Leiß (2007), Galbraith and Stillman (2006), and Eraslan and Kant (2015) stated in their studies that students had difficulties in understanding and interpreting the data in the problem.

With the Parking Lot Problem MEA, students used their mathematical skills and tools to make predictions and assumptions, analyze the problems, and study carefully. Swan et al. (2007) used modeling activities with middle school students in their work. They stated that students could work with mathematical skills and tools to make predictions, assumptions, error analysis, and study carefully while creating mathematical representations (models).

In the Parking Lot Problem MEA, the students in both groups decided to draw the parking lot at an angle of $60^{\circ}$ using a protractor and ruler, but they had great difficulty. As one group did not have much time left, they gave up drawing and drew straight at a $90^{\circ}$ angle, while the other group completed their parking lots by drawing at $60^{\circ}$ with some mistakes. Both groups lost much time in this process. Secondary school 8th-grade students had difficulty drawing identical shapes using a protractor and ruler, and they also stated that they had difficulty in one-to-one and group meetings. This result suggests that teachers from primary school to secondary school may not have allocated enough time for teaching geometry-related acquisitions in their curriculum and have not had the relevant studies/applications done.

In the applied modeling activity, the students discussed a lot at some stages, especially after understanding the problem; they lost much time in the stage of establishing a model, which is the stage of making appropriate assumptions. In addition, while some group members were active during these discussions, some were content to listen and approve of others, and the students wanted to reach a result quickly without reaching an agreement. Greefrath (2013) stated in his study that in MEAs, students spend much time simplifying the given real-life problem and carrying out planning. In discussions, mathematical models are expressed very quickly and silently without discussion. However, in the process of modeling activities, it was observed that the students wanted to reach a result quickly without spending enough time to 
understand and analyze the problem, so they tried to get help and approval from the teacher by asking questions to the researcher frequently in the process (Blum \& Borromeo Ferri, 2009; Eraslan \& Kant, 2015; Zawojewski et al., 2003). This situation reveals that students have difficulty working in a process-based and student-centered way; they act in a result-oriented and teacher-centered way. Therefore, the curriculum and its constituent elements should be reviewed (Doruk, 2010).

During the MEA, students wanted to validate the model they created intuitively. They tried to get approval from the researcher (as their supervisor) without verification based on observation, research, measurement, and calculations and therefore had difficulty validating and verifying the model they created. This result is similar to the challenges faced by the students in the model-eliciting process presented in the literature (Sol et al., 2011; Blum \& Borromeo Ferri, 2009; Blum \& Leiß, 2007; Stillman, Galbraith, Brown \& Edwards, 2007; Zawojewski, Lesh, \& English, 2003).

The results of the study revealed that students had some difficulties in understanding the problem, creating appropriate models based on assumptions, developing a model using mathematics based on the assumed data, verifying and validating the model, working with groups, and time management. Despite these difficulties, as in the studies carried out by Mousoulides et al. (2006), although it was the first time that these students previously working with traditional problems in textbooks encountered modeling activities such as assumption, modeling, using mathematics, checking, and presenting results, thanks to the social interaction in the groups, they managed the process very successfully, examined the problem from different perspectives, established and tried hypotheses, evaluated their models, changed them with additions, and reviewed and corrected them. Besides, modeling activities have been found to allow students to work in groups. In the dimension of intra-group communication and social interaction, students gain experiences such as planning, investigation, opposing the assumptions and claims of others, and reaching a consensus as a group (Zawojewski et al., 2003). In this process, students successfully performed many calculations, associations, assumptions, tabulations, roundings, estimations, rankings, and found the arithmetic average on the model (Doruk, 2010; English, 2002; English, 2006; Eraslan \& Kant, 2015; Lesh and Harel, 2003; Swan et al., 2007).

The fact that the students encountered some difficulties in the process of modeling revealed the origins and causes of the deficiencies in the mathematics curriculum, which was created as a curriculum that ensures meaningful and permeant learning, is associated with previous learning and integrated with other dsiciplines and real life within the framework of values, skills and competencies (MoNE, 2018) . In this respect, students' limited experiences of such activities that require working in groups, generating ideas, interpreting, sharing, presenting, and interdisciplinary work can be increased with in-school and out-of-school planning. Therefore, it is considered important to provide students with environments where they can work with their peers on mathematical situations that require interpretation. At this point, environments where STEM education practices (Meyrick, 2011; Gonzalez \& Kuenzi, 2012) are planned, which are important for students to find interdisciplinary solutions to problems, provide them with $21 \mathrm{st}-$ century knowledge and skills and help them specialize in science, mathematics, engineering, and technology. 


\section{Implications}

This study aimed to reveal the mathematical modeling processes of middle school 8thgrade students in STEM education and the difficulties they encounter in MEAs. The results of the study revealed that students faced some difficulties in understanding the problem, creating appropriate models based on assumptions, using mathematics, revising their models and explaining the results, validating their models, working with groups, and time management. In general, to overcome these difficulties that students face, it is necessary to create learning environments that will enable them to have more experience in this subject by introducing MEAs, which allow them to interpret daily life problems using the language of mathematics. For this reason, modeling activities can be included in primary and secondary school education programs as STEM education practices starting from pre-school. Students can gain modeling experience from a young age with the expansion of the course of mathematical applications, included in the middle school $5^{\text {th }}$ grade curriculum, in a way to incorporate $1^{\text {st }}$ to $4^{\text {th }}$ grades. Besides, thanks to the STEM education approach, implementing interdisciplinary MEAs will enable students to recognize the relationship of mathematics with other disciplines allowing them to develop a positive attitude towards mathematics starting from the primary school level.

Other courses can be chosen in some schools at the middle school level instead of the elective Mathematics Applications course. In such cases, students can gain experience with the addition of an MEA at the end of each unit, at least in the mathematics lessons of these classes.

Teachers who are the implementers of the curriculum are expected to have the necessary knowledge and experience about modeling, mathematical modeling, and MEAs to carry out the Mathematics Applications course the includes modeling activities, in line with the objectives of the course. For this reason, in-service courses and trainings should be organized for middle school teachers during the seminar periods to help them become more competent in these matters, and teachers should be enabled to participate in these training practically. It is also recommended to give compulsory modeling and mathematical modeling courses in undergraduate education to train new generation of teachers as teachers who have the necessary equipment to implement interdisciplinary modeling activities.

Another issue is the choice of MEA to be applied in class. It has been stated in the literature that teachers who want to use MEAs in their classsroom cannot find sufficient resources (Erbaş, Kertil, Çetinkaya, Çakıroğlu, Alacacı \& Baş, 2014). There is a need for many interdisciplinary MEAs for different learning objecives at different grade levels. Therefore, similar studies are needed in this area. In this way, a website can be created where MEAs are applied and MEAs that are applicable for different grade levels are collected. Thus, teachers and researchers can choose the appropriate MEAs to implement in the classroom using this website where MEAs are presented as an open-source application.

After MEA applications are completed in the classroom, environments in which each group can interact should be provided so that students can present their models. Students can criticize the models of the students' in other groups. It will lead the students in the other groups to explain their models, defend them, and try to persuade their friends. In this way, students will realize that group success is more important than individual success, and their communication skills will be strengthened. Thus, while creating environments where students work in cooperation, exam-oriented competitive environments should be removed from compulsory education. With the abolition of the central and competitive examination system, teachers' concerns about developing programs will be eliminated, and more time will be allocated to MEAs. In this way, students who receive modeling training from an early age will acquire creativity, high-level 
thinking skills, communication and social development, and 21st-century skills. Besides, new research on MEAs will be expanded to pre-school, primary, secondary, and higher education students, examining their MEA processes, determining whether the information about modeling has developed over time, and examining the effect of modeling mathematics on these developments. It will also contribute to the deepening and enrichment of the limited literature.

\section{Information}

We would like to thank Mersin University Scientific Research Projects (BAP) Unit for their support of this study (Project No: 2019-3-TP2-3736).

The paper is based on the master thesis of the first author (master degree completed at the Institute of Educational Sciences of Mersin University in 2020).

\section{References}

Balakrıshnan, G., Yen, Y.P., \& Goh, E. L. E. (2010). Mathematical modelling in the Singapore secondary school mathematics curriculum. In Mathematical Applications And Modelling: Yearbook 2010, Association of Mathematics Educators (pp. 247-257).

Ben-Chaim, D., Fey, J., Fitzgerald, W., Benedetto, C., \& Miller, J. (1997). Development of proportional reasoning in a problem-based middle school curriculum. Annual Meeting of the American Educational Research Association, Chicago, IL. Achieved at 30.03.2021. https://files.eric.ed.gov/fulltext/ED412091.pdf

Berry, J. S., \& Houston, K. (1995). Mathematical modelling. Gulf Professional Publishing.

Blum, W. (2011). Can modelling be taught and learnt? Some answers from empirical research. In G. Kaiser, W. Blum, R. Borromeo Ferri, \& G. Stillman (Eds.), Trends in Teaching and Learning of Mathematical Modelling. International Perspectives on the Teaching and Learning of Mathematical Modelling (pp. 15-30). New York: Springer.

Blum, W., \& Borromeo Ferri, R. (2009). Mathematical modelling: Can it be taught and learnt? Journal of mathematical modelling and application, 1(1), 45-58.

Blum, W., \& Leiß, D. (2007). How Do Students and Teachers Deal With Modeling Problems? In C. R. Haines, P. Galbraith, W. Blum \& S. Khan (Eds.), Mathematical Modeling Education, Engineering and Economics (pp. 222-231). Chichester: Horwood Publishing.

Borromeo Ferri, R. (2006). Theoretical and empirical differentiations of phases in the modelling process. Zentralblatt für Didaktik der Mathematik-ZDM, 38(2), 86-95

Bryan, L. A., Moore, T. J., Johnson, C. C., \& Roehrig, G. H. (2015). Integrated STEM education. In STEM road map (pp. 23-37). Routledge.

Bulgar, S. (2008). Enabling more students to achieve mathematical success. Creativity, giftedness and talent development in mathematics, 133-154.

Chan, E. C. M. (2008). Using model-eliciting activities for primary mathematics classrooms. The Mathematics Educator, 11(1), 47-66.

Corlu, M. S., Capraro, R. M., \& Capraro, M. M. (2014). Introducing STEM education: Implications for educating our teachers in the age of innovation. Education and Science, 39(171), 74-85.

Creswell, J. W. (2019). Eğitim raştırmaları: Nicel ve nitel araştırmanın planlanması, yürütülmesi ve değerlendirilmesi [Educational research: Planning, conducting and evaluating quantitative and qualitative research] (translated by $\mathrm{H}$. Ekşi). İstanbul: EDAM Publishing.

Creswell, J. W. (2018). Nitel Araştırma Yöntemleri [Qualitative Research Methods] (M. Bütün ve S. B. Demir, Çev.). Ankara: Siyasal Kitabevi. 
Doerr, H. M. (1997). Experiment, simulation and analysis: An integrated instructional approach to the concept of force. International journal of science education, 19(3), 265-282.

Doğan, M. F., Gürbüz, R., Çavuş Erdem, Z., \& Şahin, S. (2019a). STEM eğitimine geçişte bir araç olarak matematiksel modelleme. [Mathematical modeling as a tool in transition to STEM education] R. Gürbüz ve M. F. Doğan (Ed.). Matematiksel modellemeye disiplinler arası bakış: Bir STEM yaklaşımı (3. Baskı) içinde (s. 43-56). Ankara: Pegem Akademi.

Doğan, M. F., Gürbüz, R., Çavuş Erdem, Z., \& Şahin, S. (2019b). Using Mathematical Modeling for Integrating STEM Disciplines: A Theoretical Framework. Turkish Journal of Computer and Mathematics Education (TURCOMAT), 10(3), 628-653.

Doruk, B. K. (2010). Matematiği günlük yaşama transfer etmede matematiksel modellemenin Etkisi. [Effect of mathematical modeling on transferring mathematics to daily life.] Unpublished PhD Thesis, Hacettepe Üniversitesi Sosyal Bilimler Enstitüsü, Ankara.

English, L. D. (2002). Development of 10-Year-Olds' Mathematical Modelling. In: Proceedings of the Annual Meeting of the International Group for the Psychology of Mathematics Education (26th, Norwich, England, July 21-26, 2002).

English, L. D. (2006). Mathematical modeling in the primary school: Children's construction of a consumer guide. Educational studies in mathematics, 63(3), 303-323.

English, L. D. (2009). Promoting interdisciplinarity through mathematical modelling. Zentralblatt für Didaktik der Mathematik -ZDM, 41(1-2), 161-181.

English, L. D., \& Kirshner, D. (Eds.). (2015). Handbook of international research in mathematics education. Routledge.

English, L. D., \& Mousoulides, N. G. (2011). Engineering-based modelling experiences in the elementary and middle classroom. In Models and modeling (pp. 173-194). Springer, Dordrecht.

Eraslan, A., \& Kant, S. (2015). Modeling processes of 4th-year middle-school students and the difficulties encountered. Educational Sciences: Theory \& Practice, 15(3).

Erbaş, A. K., Kertil, M., Çetinkaya, B., Çakıroğlu, E., Alacacı, C., \& Baş, S. (2014). Matematik eğitiminde matematiksel modelleme: Temel kavramlar ve farklı yaklaşımlar. [Mathematical modeling in mathematics education: Basic concepts and different approaches.] Educational Sciences:Theory and Practice, 14(4), 1-21.

Eş, H., Özdemir, A., \& Kaplan, M. (2019). Matematik Bir Bilim Dalı Mıdır? Matematik Öğretmen Adaylarının Bilim-Matematik İlişkisine Dair Algıları. [Is Mathematics a Branch of Science? Mathematics Teacher Candidates' Perceptions of the Relationship between Science and Mathematics]. Kastamonu Education Journal, 27(1), 407-419.

Galbraith, P., \& Stillman, G. (2006). A framework for identifying student blockages during transitions in the modelling process. Zentralblatt für Didaktik der MathematikZDM, 38(2), 143-162.

Gonzalez, H. B., \& Kuenzi, J. J. (2012). Science, technology, engineering, and mathematics (STEM) education: A primer. Washington, DC: Congressional Research Service, Library of Congress.

Greefrath, C. (2013). Analysis of modelling problem solutions with methods of problem solving. In Lesh, R., Galbraith, P. L., Haines, C. R., \& Hurford, A (Eds.), Modeling students' mathematical modeling competencies: The 13th. ICTMA study (pp. 265-271). Springer, Dordrecht.

Hestenes, D. (2010). Modeling theory for math and science education. In Modeling students' mathematical modeling competencies (pp. 13-41). Springer, Boston, MA.

Hıdıroğlu, Ç. N. (2012). Teknoloji destekli ortamda matematiksel modelleme problemlerinin çözüm süreçlerinin analiz edilmesi: Yaklaşım ve düşünme süreçleri üzerine bir açıklama. [Analyzing the solution processes of mathematical modeling problems in a 
technology-supported environment: An explanation on the approach and thinking processes]. Unpublished Master Thesis. Dokuz Eylül University, Institute of Educational Sciences, İzmir.

Kertil, M. (2008). Matematik öğretmen adaylarının problem çözme becerilerinin modelleme sürecinde incelenmesi. [Examination of pre-service mathematics teachers' problem solving skills in the modeling process.]. Unpublished Master Thesis. Marmara University, Institute of Educational Sciences, İstanbul.

Kertil, M., \& Gurel, C. (2016). Mathematical modeling: A bridge to STEM education. International Journal of Education in Mathematics Science and Technology, 4(1), 44-55.

Kuenzi, J. J. (2008). Science, technology, engineering, and mathematics (STEM) education: Background, federal policy, and legislative action. Achieved at 30.03.2021: http://digitalcommons.unl.edu/crsdocs/35/

Lesh, R., \& Doerr, H. M. (2003). Foundations of a models and modeling perspective on mathematics teaching, learning, and problem solving. R. Lesh ve HM Doerr (Eds), Beyond constructivism: Models and modeling perspectives on mathematics problem solving, learning, and teaching, 3-33.

Lesh, R., \& English, L. (2017). Case Study for Kids. Achieved at 30.03.2021: https://engineering.purdue.edu/ENE/Research/SGMM/CASESTUDIESKIDSWEB/ind ex.htm

Lesh, R., \& Harel, G. (2003). Problem solving, modeling, and local conceptual development. Mathematical thinking and learning, 5(2-3), 157-189.

Lesh, R. A., ve Zawojewski, J. S. (2007). Problem Solving and Modeling. In F. Lester (Eds.), Second Handbook of Research on Mathematics Teaching and Learning: A Project of the National Council of Teachers of Mathematics (s. 763-804). Charlotte, NC: Information Age Publishing.

Meyrick, K.M. (2011). How STEM education improves student learning. Meridian K12 School Computer Technologies Journal, 14(1), 1-6.

Ministry of National Education (MoNE) [Millî Eğitim Bakanlığı (MEB)] (2016). STEM Eğitimi Raporu. [STEM Education Report]. Ankara: Millî Eğitim Bakanlığg Yenilik ve Eğitim Teknolojileri Genel Müdürlüğü (YEĞİTEK). Achieved at 30.03.2021: http://yegitek.meb.gov.tr/STEM_Egitimi_Raporu.pdf .

Ministry of National Education (MoNE) [Millî Eğitim Bakanlığı (MEB)] (2018). Matematik Dersi Öğretim Programı (İlkokul ve Ortaokul 1,2, 3, 4, 5, 6, 7 ve 8. sinıflar) [Mathematics Curriculum (Primary and Secondary Schools 1, 2, 3, 4, 5, 6, 7 and 8th grades).]. Ankara: MEB Publishing

Moore, T.J., Doerr, H.M., Glancy, A.W., \& Ntow, F.D. (2015). Preserving pelicans with models that make sense. Mathematics Teaching in the Middle School, 20(6), 358-364.

Mousoulides, N., Pittalis, M., \& Christou, C. (2006). Improving Mathematical Knowledge through Modeling in Elementary School. In Proceedings of 30th Conference of the PME (Vol. 4, pp. 201-208).

National Council of Teachers of Mathematics. (2000). Principles and standards for school mathematics (1). Achieved at 30.03.2021: http://www.nctm.org/uploadedFiles/ Standards_and_Positions/PSSM_ExecutiveSummary.pdf

Olkun, S., \& Uçar, Z. T. (2009). Illköğretimde etkinlik temelli matematik ögretimi. [Activitybased mathematics teaching in primary education] Ankara: Eğiten Kitap Yayınevi

Organisation for Economic Co-operation and Development (2010). Education at a glance 2010: OECD indicators. Paris: OECD. 
Patton, M. Q. (2014). Nitel araştırma ve değerlendirme yöntemleri [Qualitative Research \& Evaluation Methods] (M. Bütün ve S.B. Demir, Çev. Ed.). Ankara: Pegem Akademi.

Şahin, A., Ayar, M. C., \& Adiguzel, T. (2014). STEM Related After-School Program Activities and Associated Outcomes on Student Learning. Educational Sciences: Theory and Practice, 14(1), 309-322.

Sol, M., Giménez, J., \& Rosich, N. (2011). Project Modelling Routes in 12-16-Year-Old Pupils. In G. Kaiser, W. Blum, R. B. Ferri, G. Stillman (Eds.), Trends in Teaching and Learning of Mathematical Modeling: The 14. ICMTA Study (pp. 231-240). New York: Springer.

Sriraman, B., \& Lesh, R. A. (2006). Modeling conceptions revisited. Zentralblatt für Didaktik der Mathematik-ZDM, 38(3), 247-254.

Stillman, G., Galbraith, P., Brown, J., \& Edwards, I. (2007). A framework for success in implementing mathematical modelling in the secondary classroom. Mathematics: Essential research, essential practice, 2, 688-697.

Swan, M., Turner, R., Yoon, C., \& Muller, E. (2007). The roles of modelling in learning mathematics. In W. Blum, P. Galbraith, H.-W. Henn \& M. Niss (Eds.) Modelling and applications in mathematics education: The 14th ICMI study (pp. 275-284). Springer, Boston, MA.

Şimşek, H., \& Yıldırım, A. (2011). Sosyal bilimlerde nitel araştırma yöntemleri. [Qualitative research methods in the social sciences.] Ankara: Seçkin Publishing.

Turner, R. (2007). Modelling and applications in PISA. In Modelling and applications in mathematics education (pp. 433-440). Springer, Boston, MA.

Umay, A. (1996). Matematik öğretimi ve ölçülmesi. [Teaching and measuring mathematics.] Hacettepe University Journal of Education, 12, 145-149

Yamak, H., Bulut, N., \& Dündar, S. (2014). 5. sınıf öğrencilerinin bilimsel süreç becerileri ile fene karşı tutumlarına FeTeMM etkinliklerinin etkisi. [The effect of STEM activities on 5th grade students' scientific process skills and attitudes towards science.] Gazi University Journal of Gazi Education Faculty, 34(2), 249-265.

Yin, R. K. (2017). Durum çalışması araştırması uygulamaları [Case study research applications] (translated by İ. Günbayı). Ankara: Nobel Publishing.

Zawojewski, J. S., Lesh, R. A., \& English, L. D. (2003). A models and modeling perspective on the role of small group learning activities. In Beyond constructivism: Models and modeling perspectives on mathematics problem solving, learning, and teaching (pp. 337-358). Lawrence Erlbaum Associates. 